\title{
Erratum to: Effect of process parameters on microstructure and mechanical properties of friction stir-welded Ti-6Al-4V joints
}

\author{
A. Fall $^{1}$ - M. Jahazi ${ }^{1}$ A. R. Khodabandeh ${ }^{2} \cdot$ M. H. Fesharaki ${ }^{2}$
}

Published online: 11 May 2017

(C) Springer-Verlag London 2017

Erratum to: Int J Adv Manuf Technol (2016)

DOI: 10.1007/s00170-016-9527-y

This article originally published with the author family name incorrectly listed. The author name have now been appear correctly above. The original article was corrected.

The online version of the original article can be found at http://dx.doi.org/ 10.1007/s00170-016-9527-y

\footnotetext{
A. Fall

ameth-maloum.fall.1@ens.etsmtl.ca
}

1 Ecole de Technologie Supérieure (E.T.S.), Département de Génie Mécanique, 1100 Rue Notre-Dame Ouest, Montréal, QC H3C 1K3, Canada

2 Science and Research Branch, Islamic Azad University, Teheran, Hesarak, Iran 